JERZY J. PARYSEK

\title{
MIASTO W UJĘCIU SYSTEMOWYM
}

\section{WPROWADZENIE}

Od czasu sformułowania przez Ludwiga von Bertalanffy'ego ogólnej teorii systemów systemowe ujęcia przedmiotu zainteresowań znajdują coraz większe zastosowanie w określaniu przedmiotu badań w różnych dziedzinach wiedzy. To właśnie złożoność różnego rodzaju przedmiotów zainteresowania naukowego przesądza o popularności tego, sformułowanego na gruncie nauk biologicznych, ujęcia. Złożoność, którą określają: wielość elementów składających się na funkcjonalną całość nazywaną systemem oraz wielość relacji, zarówno między elementami tego systemu, jak i między tymi elementami a otoczeniem systemu. O popularności systemowego ujęcia decydują zatem przede wszystkim: całościowość ujęcia przedmiotu badań, jego funkcjonalność oraz teleologiczny (celowościowy) charakter jego zachowania ${ }^{1}$. Wydaje się, że w ujęciu systemowym szczególnie ważną rolę odgrywa właśnie sieć wielu, różnego rodzaju relacji między elementami, stanowiacych o funkcjonalności systemu, na co, jeszcze przed sformułowaniami L. von Bertalanffy'ego, zwrócił uwagę W. Leontief, formułując model powiązań w gospodarce Stanów Zjednoczonych, nazywany modelem input-output. W gospodarce, która w istocie rzeczy jest systemem.

Systemowe ujęcie przedmiotu badań wywodzi się, jak to już napisano, z biologii, gdzie systemami są organizmy żywe. Później ujęcie systemowe przyjęto także w innych dziedzinach nauki i do dziś można mówić o adaptowaniu dwóch charakterystycznych modeli systemów, tj. organicystycznym (organistycznym) i mechanistycznym, pozwalających odwzorować, badać i opisać obserwowana rzeczywistość ${ }^{2}$. Dla tego pierwszego modelu wzorcem jest organizm, dla tego drugiego zaś - maszyna. Zarówno organizm, jak i maszyna stanowią bez wątpienia określone, funkcjonalne całości. Funkcjonalność organizmu wyraża się $\mathrm{w}$ jego w sumie bardzo złożonym życiu, natomiast maszyny w jej dużo prostszym w stosunku do życia funkcjonowaniu, działaniu, czyli pracy ${ }^{3}$.

Analizując miasto, w tym wielość tworzących tę całość elementów, ogrom różnorodnych relacji łączących składniki miasta oraz łączących te składniki

${ }^{1}$ L. von Bertalanffy, An Outline of General System Theory, „British Journal of the Philosophy of Science" 1, 1950, nr 2, s. 134-165; idem, General System Theory: Foundations, Development, Application, G. Braziller, New York 1968; idem, Historia rozwoju i status ogólnej teorii systemów, w: G. J. Klir (red.), Ogólna teoria systemów, WNiT, Warszawa 1976, s. 27- 47.

${ }^{2}$ Ibidem. G. J. Klir (red.), op. cit.

${ }^{3}$ Ibidem. 
z otoczeniem (strefą zewnętrzną bliższą i dalsza), a także funkcjonowanie miasta, jako środowisko życia człowieka, mamy prawo, jak się wydaje, potraktować miasto jako system. Prawdopodobnie pierwszą osobą w Polsce, która zwróciła uwagę na możliwość wykorzystania ogólnej teorii systemu do badania i planowania rozwoju miasta, był B. Jałowiecki, mając na uwadze propozycje przedstawione przez B. M. Grossa ${ }^{4}$.

Analizując strukturę przestrzenno-funkcjonalną miasta łatwo dojść do wniosku, że bardziej adekwatnym modelem dla systemu miasta jest organizm, a nie mechanizm, choćby biorąc pod uwagę składniki miasta oraz funkcjonowanie (zachowanie) tego systemu, jakkolwiek przyjęcie modelu organicystycznego przysparzać może wielu różnej natury problemów w procesie badania miasta, jego organizacji, struktury i funkcjonowania.

Miasto jest wysoce złożonym wytworem działalności człowieka, pełniącym rolę środowiska życia, w istocie rzeczy antropogenicznego. Jako takie jest w coraz większym stopniu świadomie i celowo kształtowanym przez władze samorządowe i społeczności lokalne. Mimo tego jest ciagle miejscem koncentracji niekorzystnych dla człowieka rzeczy, zdarzeń i procesów, które rodzą problemy wymagające możliwie szybkiego i kompleksowego rozwiązania. Wydaje się zatem, że tego właśnie rodzaju sytuacja współczesnych miast legła u podstaw zainicjowania przez Unię Europejską prac na rzecz wypracowania i wdrożenia przez poszczególne kraje członkowskie polityki miejskiej, co znalazło swój wyraz m.in. w zapisie Karty Lipskiej ${ }^{5}$. Jest zatem wysoce prawdopodobne, że wiele z pojawiających się problemów funkcjonowania i rozwoju miasta znaleźć może i oryginalne i efektywne sformułowanie oraz skuteczne rozwiązanie właśnie w ujęciu systemowym.

Celem niniejszego artykułu jest przedstawienie trzech, jak się wydaje, charakterystycznych ujęć systemowych miasta. Będą to: 1) miasto potraktowane, jako terytorialny system społeczny (systemowe ujęcie społeczno-ekonomiczne), 2) miasto potraktowane, jako ekosystem (systemowe ujęcie ekologiczne) i 3) miasto potraktowane jako system organiczny (miasto-organizm, systemowe ujęcie organicystyczne).

\section{MIASTO: OD UJECCIA NOMINALNEGO DO UJĘCIA SYSTEMOWEGO}

Od najdawniejszych czasów miasto jest przedmiotem badań naukowych, będąc w kręgu zainteresowania historyków, geografów, urbanistów, architektów, planistów, ekologów, socjologów, psychologów społecznych, antropologów,

${ }^{4}$ B. Jałowiecki, op. cit.

${ }^{5}$ J. Parysek, Rozwój miast a polityka miejska w Polsce po 1989 roku, w: S. Ciok, P. Migoń (red.), Przeksztatcenia struktur regionalnych, Aspekty spoteczne, ekonomiczne i przyrodnicze, Uniwersytet Wrocławski, Instytut Geografii i Rozwoju Regionalnego, Wrocław 2010, s. 117-132; J. J. Parysek, Urban Development Policy of the European Union and the Discretionary Nature of Polish Spatial Planning, w: P. Churski, W. Ratajczak (red.), Regional Development and Regional Policy in Poland: First Experiences and new Challenges of the European Union Membership, Part I, KPZK PAN, Studia Regionalia, t. 27, cz. 1, Warszawa 2010, s. 172-184. 
ekonomistów, politologów, przyrodników, inżynierów komunalnych, prawników, kulturoznawców i zapewne przedstawicieli wielu innych dyscyplin naukowych. Jest jednak przede wszystkim przedmiotem badań: urbanistów, architektów, socjologów, ekonomistów, politologów oraz geografów (tab. 1).

\section{Tabela 1}

Miasto jako multidyscyplinarny przedmiot badań naukowych

\begin{tabular}{|c|c|c|}
\hline $\begin{array}{c}\text { Dyscyplina } \\
\text { naukowa }\end{array}$ & $\begin{array}{c}\text { Pojmowanie } \\
\text { miasta }\end{array}$ & Podstawowa problematyka badawcza \\
\hline Urbanistyka & $\begin{array}{l}\text { Miasto, jako fizyczna struk- } \\
\text { tura wypełniająca określone } \\
\text { funkcje }\end{array}$ & $\begin{array}{l}\text { Właściwe zaprojektowanie i rozmieszczenie } \\
\text { budynków i sieci infrastruktury komunalnej; } \\
\text { tworzenie optymalnych struktur przestrzenno- } \\
\text {-funkcjonalnych }\end{array}$ \\
\hline Socjologia & $\begin{array}{l}\text { Miasto, jako zbiór elemen- } \\
\text { tów kulturowych i relacji } \\
\text { (więzi społecznych) }\end{array}$ & $\begin{array}{l}\text { Interakcje między fizyczną a społeczną natura } \\
\text { miasta; procesy społeczne zachodzące w mieście; } \\
\text { miasto, jako środowisko życia (ekologia społecz- } \\
\text { na, miejska); konflikty społeczne w miastach }\end{array}$ \\
\hline Ekonomia & $\begin{array}{l}\text { Miasto jako miejsce prowa- } \\
\text { dzenia działalności gospo- } \\
\text { darczej oraz rynek }\end{array}$ & $\begin{array}{l}\text { Czynniki lokalizacji i koncentracji podmiotów } \\
\text { gospodarczych w mieście; miasta, jako bieguny } \\
\text { wzrostu; koszty funkcjonowania miasta; konku- } \\
\text { rencyjność miast }\end{array}$ \\
\hline $\begin{array}{l}\text { Nauki } \\
\text { polityczne }\end{array}$ & $\begin{array}{l}\text { Miasto, jako specyficzna } \\
\text { jednostka administracyj- } \\
\text { na, miejsce podejmowania } \\
\text { decyzji politycznych }\end{array}$ & $\begin{array}{l}\text { Badanie politycznych procesów toczących się } \\
\text { w miastach w nawiązaniu do struktury prze- } \\
\text { strzennej miasta i struktur społecznych; zarza- } \\
\text { dzanie zasobami miejskimi i miastem, jako cało- } \\
\text { ścią; instytucjonalne milieu miasta }\end{array}$ \\
\hline Geografia & $\begin{array}{l}\text { Miasto, jako struktura } \\
\text { przestrzenno-funkcjonal- } \\
\text { na, lokalny terytorialny } \\
\text { system społeczny }\end{array}$ & $\begin{array}{l}\text { Fizyczna struktura miasta, struktura użytko- } \\
\text { wania ziemi w mieście, struktura przestrzenno- } \\
\text {-funkcjonalna miasta, rozwój miast i czynniki } \\
\text { rozwoju, funkcje miast, regionotwórcza rola } \\
\text { miast; miasta, jako generatory rozwoju (gospo- } \\
\text { darka oparta na wiedzy, sektory kreatywne roz- } \\
\text { woju) itp. }\end{array}$ \\
\hline
\end{tabular}

Źródło: J. Parysek, L. Mierzejewska, Życie miasta. Studium Poznania. Miasto i jego mieszkańcy, Bogucki Wydawnictwo Naukowe, Poznań 2013.

Dla geografów i urbanistów miasto jest przedmiotem badań o bardzo szerokim zakresie rzeczowym i problemowym. Badano i bada się do dziśs m.in.: genezę miast, czynniki ich lokalizacji, rozwój ludnościowy, gospodarczy, społeczny i przestrzenny, czynniki tego rozwoju, architekturę i zabudowę miast, układy przestrzenne, upadek miast i przyczyny tego procesu, funkcje miast i ich zmiany, miejskie struktury gospodarcze, struktury społeczne, działalność podmiotów gospodarczych, regionotwórczą funkcję miast, ekologię miast, struktury przestrzenno-funkcjonalne, procesy demograficzno-społeczne, warunki życia w mieście, mobilność ludności miejskiej, procesy metropolizacji, rolę miast w procesach globalizacyjnych itp. Silne oddziaływanie zewnętrzne miasta stało 
się natomiast przyczyną podjęcia badań obejmujaccych zagadnienia czynników powstawania stref podmiejskich i regionów miejskich, kształtowania się aglomeracji i procesów rozwojowych tych struktur przestrzenno-funkcjonalnych, kształtowania się struktur wewnętrznych aglomeracji, procesów suburbanizacji itp. Co więcej, przedmiotem zainteresowania tych dyscyplin naukowych jest planowanie rozwoju miast, projektowanie miast (urban design), kształtowanie zabudowy, poprawa funkcjonalności i efektywności funkcjonowania miasta, poprawa ładu przestrzennego, rozwój zrównoważony, rewitalizacja, ekonomika miejska itp. Wszystko to podejmuje się przede wszystkim w celu poprawy warunków życia i obsługi ludności oraz obniżenia społecznych kosztów funkcjonowania miasta.

$\mathrm{W}$ badaniach dotyczących miasta (szczególnie zaś w badaniach geograficznych) miasto traktowane jest jako przedmiot badań, który opisuje nazwa własna oraz położenie geograficzne, najczęściej odwzorowane na mapie. Dla tak określonego, jednostkowego przedmiotu badań (np. Poznania, Kalisza, Sycowa) lub zbioru takich przedmiotów (np. 30 największych miast Polski lub zbiór miast województwa śląskiego) ustala się zakres rzeczowy prowadzonych badań. Zakres prowadzonych badań, bez względu na to, czy mamy do czynienia z pojedynczym miastem czy ze zbiorem miast, obejmuje najczęściej liczbę ludności miasta i inne charakterystyki demograficzne, funkcje miasta, migracje, zatrudnienie, bezrobocie, poziom rozwoju gospodarczego, strukturę gospodarcza, strukturę społeczna, infrastrukturę techniczną i społeczna, użytkowanie ziemi, zagospodarowanie przestrzenne, układ urbanistyczny, majątek trwały, budżet, poziom życia, zjawiska patologiczne itp. Badania te mogą dotyczyć określonych stanów rzeczy, tj. konkretnego cięcia czasowego (np. roku 2013), zmiany stanów rzeczy, czyli zdarzeń (np. porównania stanów rzeczy w roku 2001 i 2010) względnie procesów, czyli uporządkowanych względem biegu czasu, kolejnych zmian stanów rzeczy (np. zmiany w kolejnych latach okresu 2001-2014). Badanie procesów można w pewnym sensie potraktować jako przejaw życia miasta, np. społecznego, gospodarczego, kulturalnego, religijnego, politycznego itp. Tego rodzaju ujęcie można nazwać nominalnym, obiekt będący przedmiotem badań (zbiór obiektów) reprezentuje bowiem jego nazwa (zbiór nazw) i jest ono tak stare, jak stare są badania dotyczace miast.

Innym ujęciem miasta jako przedmiotu badań jest potraktowanie go jako jednostki przestrzennej. Bierze się wtedy pod uwagę pewien, wyznaczony przez konwencjonalnie przyjęte granice, wycinek skorupy ziemskiej, który w najprostszym ujęciu traktowany jest najczęściej tak, jak geometryczna przestrzeń euklidesowa. Dla tego rodzaju ujęć charakterystyczne jest uwzględnianie powierzchni miasta, odległości w obrębie tej powierzchni, kształtu i długości granic oraz sąsiedztwa miasta, jako całości i wyróżnionych jego części. Często jednak miasto oraz poszczególne jego części opisywane są wskaźnikami charakteryzujacymi środowisko przyrodnicze, społeczne, ekonomiczne, użytkowanie ziemi, zabudowę, układy urbanistyczne, strukturę przestrzenna, strukturę funkcjonalną czy traktowane ogólnie, zagospodarowanie przestrzenne itp. 
Uwzględnianie aspektów przestrzennych w badaniu miast (będące w pewnym sensie ujęciem całościowym) ma swoją dość długą historię, choć miało to przede wszystkim związek z planowaniem rozwoju miasta. Klasyczne badania przestrzenno-strukturalne miast (nazwane później ekologią czynnikowa miast) zapoczątkowane zostały właściwie przez reprezentantów tzw. socjologicznej szkoły chicagowskiej, w tym szczególnie przez R. E. Parka, W. Burgessa, L. Wirtha i H. Hoyta, a następnie rozwijane przez geografów i urbanistów np.: Ch. D. Harrisa i E. L. Ullmana ${ }^{6}$. Choć generalnie rzecz ujmujac, badania osób kojarzonych ze szkołą chicagowską obejmowały struktury społeczne wiązane z określonymi formami użytkowania ziemi w mieście (struktury rezydencjalne), to nowatorskość podejścia badawczego polegała na przeniesieniu na grunt miejskich badań społecznych, założeń ekologii, głównie ekologii roślin? Miejskie badania przestrzenno-strukturalne wkrótce jednak wykroczyły poza ten zakres, jaki można by wiązać z wyrosłą na gruncie szkoły chicagowskiej ekologia miejska. Podjęto bowiem badania nad społeczno-ekonomiczna strukturą przestrzenno-funkcjonalną miast i jej zmianami, lokalizacją w granicach miasta podmiotów gospodarczych, układami sieci komunikacyjnej miast, kształtowaniem sieci infrastruktury komunalnej, jej dostępnościa, obszarami rezydencjalnymi miast, zmianami form zagospodarowania przestrzennego, degradacją substancji materialnej miast i jej rewitalizacja, przestrzeniami publicznymi, strukturami sassiedzkimi, obszarami deprywacji i patologii społecznych, rozlewaniem się zabudowy miejskiej (urban sprawl) itp.

Zupełnie nowe światło na badanie miast rzuciło jednak ujęcie systemowe, czyli takie, które traktowało miasto, jako złożona, funkcjonalną całość.

Ujęcia systemowe w polskiej geografii społeczno-ekonomicznej proponowali stosować już w końcu lat siedemdziesiątych XX w. Z. Chojnicki i T. Czyż ${ }^{8}$. Kluczową rolę w systemowym podejściu do przedmiotu badań geograficznych odegrało jednak dopiero sformułowanie przez Z. Chojnickiego ${ }^{9}$ koncepcji terytorialnego systemu społecznego. Koncepcja ta została następnie rozciagnięta na inne systemy społeczne, będacce - obok socjologii i psychologii społecznej także przedmiotem badań geograficznych oraz urbanistycznych ${ }^{10}$. Miasto, jako jednostka przestrzenna spełnia bowiem wszystkie warunki, jakie powi-

${ }^{6}$ A. J. Cortese, The Rise, Hegemony and Decline of the Chicago School of Sociology (18921945), „Social Science Journal” 32, 1995, s. 235-254; P. Korcelli, Teoria rozwoju struktury przestrzennej miast, KPZK PAN 45, PWN, Warszawa 1974; B. Jałowiecki, op. cit.; B. Jałowiecki, M. S. Szczepański, Miasto i przestrzeń w perspektywie socjologicznej, Scholar, Warszawa 2002; W. Maik, Ewolucje teoretyczno-metodologiczne studiów miejskich $w$ świetle zmieniajacych się konceptualizacji miasta, w: J. Parysek, T. Stryjakiewicz (red.), Region społeczno-ekonomiczny i rozwój regionalny, Bogucki Wydawnictwo Naukowe, Poznań 2008, s. 77-90; M. Pacione, Urban Geography: A Global Perspective, Routledge, Abingdon 2009.

7 A. J. Cortese, op. cit.; M. Pacione, op. cit.

8 Z. Chojnicki, T. Czyż, Analiza systemowa w geografii, „Czasopismo Geograficzne” 49, 1978, nr 3, s. 265-286.

9 Z. Chojnicki, Koncepcja terytorialnego systemu społecznego, „Przegląd Geograficzny” 60, 1989, nr 3, s. 491-510.

${ }_{10}$ Z. Chojnicki, Systemy społeczne jako przedmiot geografii społeczno-ekonomicznej, w: L. Mierzejewska, M. Wdowicka (red.), Współczesne problemy rozwoju miast $i$ regionów, Bogucki Wydawnictwo Naukowe, Poznań 2011, s. 31-47. 
nien spełniać obiekt uznawany zarówno za system społeczny, jak i za terytorialny system społeczny ${ }^{11}$. Koncepcję terytorialnego systemu społecznego odniosła do miasta i jego zrównoważonego rozwoju L. Mierzejewska ${ }^{12}$. Autorka ta traktuje także miasto jako ekosystem, będący w gruncie rzeczy specyficzna kategoria terytorialnego systemu społecznego, a jednocześnie środowiskiem życia mieszkańców. Autor niniejszego opracowania rozwija natomiast systemowe, organicystyczne ujęcie miasta jako przedmiotu badań i działań praktycznych ${ }^{13}$.

Prawdopodobnie pierwszym geografem, który potraktował miasto, jako system był B. Berry ${ }^{14}$ i od tego czasu wielu badaczy miast traktuje tę jednostkę badawczą jako funkcjonalna, przestrzenną całość, adaptując ujęcie systemowe do różnych konceptualizacji miasta ${ }^{15}$. Pewnego rodzaju ujęcie systemowe w odniesieniu do miasta zaproponowali R. Funck i U. Blum ${ }^{16}$, wyróżniając trzy podsystemy systemu miasta, tj. 1) ludność miejska, 2) prywatne i publiczne zasoby kapitałowe oraz 3) zasoby naturalne miasta. Tak określony system stanowił element większego metasystemu, obejmującego inne miasta (system miast określonego poziomu przestrzennego) oraz obszary wiejskie danego terytorium. Dla tego metasystemu, w społecznym i politycznym znaczeniu, charakterystyczne były przede wszystkim struktury: technologiczne, instytucjonalne oraz behawioralne. Relacje między systemem miasta a metasystemem, w skład którego wchodzi dane miasto, sprowadzić można do procesów ekonomicznych, społeczno-kulturowych oraz politycznych i administracyjnych, których efektami działania sa odpowiednio: czynniki produkcji, czynniki jakości środowiska miejskiego oraz czynniki sprawności politycznej i instytucjonalnej, ważne dla funkcjonowania systemu ${ }^{17}$. W tym kontekście uprawnione wydaje się pojmowanie miasta jako: 1) systemu w ogóle, tj. bez określania charakteru, 2) terytorialnego systemu społecznego, 3) ekosystemu czy 4) systemu w ujęciu organicystycznym. Przyjęcie konkretnej koncepcji systemowej czy konkretnego modelu systemowego zależeć zaś będzie przede wszystkim od podejmowanej problematyki badawczej i działalności praktycznej, której dane ujęcie ma służyć.

${ }^{11}$ Ibidem. J. Parysek, Miasta polskie na przełomie XX $i$ XXI wieku: rozwój i przekształcenia strukturalne, Bogucki Wydawnictwo Naukowe, Poznań 2005, s. 247; J. Parysek, Wprowadzenie do gospodarki przestrzennej, WN UAM, Poznań 2006.

${ }^{12}$ L. Mierzejewska, Rozwój zrównoważony miasta: zagadnienia poznawcze i praktyczne, WN UAM, Seria Geografia 86, Poznań 2009.

${ }^{13}$ J. Parysek, L. Mierzejewska, Życie miasta. Studium Poznania. Miasto i jego mieszkańcy, Bogucki Wydawnictwo Naukowe, Poznań 2013; J. Parysek, L. Mierzejewska, Życie miasta. Studium Poznania. Infrastruktura miejska, Bogucki Wydawnictwo Naukowe, Poznań 2014.

${ }^{14}$ B. J. L. Berry, Cities as Systems within Systems of Cities, „Papers and Proceedings of the Regional Science Association” 13, 1964, s. 147-163.

${ }^{15}$ W. Maik, op. cit.

${ }^{16}$ R. H. Funck, U. H. Blum, Urban Change: A Changing Process, w: L. van den Berg, L. S. Burns, L. H. Klassen, Spatial Cycles, Gower, Aldershot 1987.

${ }^{17}$ Ibidem. 


\section{SYSTEMOWE KONCEPTUALIZACJE MIASTA}

\section{Miasto jako terytorialny system społeczny}

Koncepcja terytorialnego systemu społecznego pozwala, jak się wydaje, w sposób oryginalny odwzorować: organizację, strukturę i funkcjonowanie jednostki terytorialnego podziału kraju, a zatem względnie dobrze, całościowo bowiem i funkcjonalnie, opisać przedmiot badań, czyli konkretnie miasto. Istota terytorialnego systemu społecznego polega na tym, że jest identyfikowany z jednostkami terytorialnego podziału kraju, co oznacza, że ma jednoznacznie określone granice. Można więc wyróżnić terytorialny system społeczny gminy (miasta), powiatu, województwa (regionu) czy też kraju. Wszystkie te jednostki terytorialne uznać bowiem można za terytorium, czyli obszar o jednoznacznie określonych granicach, zamieszkiwany przez ludność o silnych, wewnętrznych więziach społecznych, mówiącą tym samym językiem, pielęgnująca tę samą tradycję, identyfikująca się z obszarem (o czym świadczą emocjonalne związki), na którym to obszarze rozciąga się panowanie określonej władzy. Uznanie gminy, a zatem i miasta za terytorialny system społeczny nie budzi więc żadnych wątpliwości ${ }^{18}$. Chojnicki uważa ponadto, że spośród różnych systemów społecznych, jakie można wyróżnić w środowisku (otoczeniu) człowieka, podstawowa rolę odgrywają właśnie terytorialne systemy społeczne. Rola ta jest szczególnie widoczna w kształtowaniu warunków życia oraz działalności ludzi.

W bardzo syntetycznym ujęciu system terytorialny można zdefiniować jako taki system społeczny, „w którym zbiorowość ludzi trwale zajmuje, zagospodarowuje i kontroluje wyodrębniony obszar powierzchni ziemi, czyli terytorium"19.

Tak jak każdy inny system, tak i terytorialny system społeczny określaja jego składniki, relacje oraz otoczenie. Zbiór różnego rodzaju relacji między elementami tworzacymi system nazywa się strukturą systemu. Jest to oczywiste, kiedy w sensie ogólnym strukturę definiuje się zazwyczaj jak system relacyjny. Chojnicki ${ }^{20}$ wyróżnia dwa podstawowe, a zarazem złożone składniki systemu, tj.: 1) warstwę społeczna, którą tworzy zbiorowość zamieszkujących dane terytorium ludzi, oraz 2) warstwę podłoża materialnego systemu. Złożoność wyodrębnionych warstw sprawia, że w zasadzie potraktować je można jako podsystemy, składające się z elementów o mniejszym lub większym poziomie złożoności. Warstwa społeczna składa się przede wszystkim z jednostek ludzkich, traktowanych jako składniki elementarne oraz ze składników (także do pewnego stopnia złożonych) obejmujących główne dziedziny aktywności ludzkiej. Chodzi tu o działalność: ekonomiczna, kulturową oraz polityczna. Warstwę podłoża tworzą natomiast: sfera elementów materialnych, przyrodniczych oraz sfera elementów materialnych - sztucznych (antropogenicznych), wytworzonych jednak z substancji naturalnych w wyniku świadomego i celowego działania człowieka. Podłoże materialne każdego terytorialnego systemu

18 Z. Chojnicki, Koncepcja; J. Parysek, Wprowadzenie do gospodarki.

19 Z. Chojnicki, Koncepcja; idem, Systemy społeczne.

${ }^{20}$ Idem, Koncepcja. 
społecznego jest wyodrębnione w postaci terytorium. Jest to ściśle określony obszar z jego zawartością materialna, naturalną i sztuczną oraz zamieszkującą ludnością ${ }^{21}$. Jest więc system, w wymiarze przestrzennym, miejscem nakładania się na siebie warstwy podłoża materialnego i warstwy społecznej.

Otoczenie w ujęciu Chojnickiego występuje w dwóch aspektach: wewnętrznym i zewnętrznym. Otoczeniem terytorialnego systemu społecznego sensu stricto jest otoczenie zewnętrzne, a zatem to wszystko, co znajduje się poza systemem, a z czym system powiązany jest relacjami tzw. zewnętrznymi. Otoczenie wewnętrzne nie jest właściwie otoczeniem całego terytorialnego systemu społecznego, a jedynie jego warstwy społecznej. Tak ujmowane otoczenie jest istotnym składnikiem warstwy podłoża materialnego (por. tab. 2). Jakkolwiekby jednak na sprawę patrzeć, otoczenie umożliwia funkcjonowanie systemu, kształtując jego spójność (otoczenie wewnętrzne) oraz otwartość czy domknięcie (otoczenie zewnętrzne).

Tabela 2

Terytorialny system społeczny (wg Z. Chojnickiego)

\begin{tabular}{|c|c|c|}
\hline Skład & Otoczenie & Struktura (relacje) \\
\hline $\begin{array}{l}\text { 1. Warstwa społeczna } \\
\text { - ludność (mieszkańcy) } \\
\text { - sfera ekonomiczna } \\
\text { - sfera kulturowa } \\
\text { - sfera polityczna } \\
\text { 2. Warstwa podłoża material- } \\
\text { nego } \\
\text { 2.1. Przyrodnicza } \\
\text { - nieorganiczna } \\
\text { - ziemia } \\
\text { - bogactwa natural- } \\
\quad \text { ne } \\
\text { - substancje, mate- } \\
\quad \text { rie, energie } \\
\text { - organiczna } \\
\text { - świat roślin } \\
\text { - świat zwierząt } \\
\text { - świat mikroorgani- } \\
\text { zmów } \\
\text { 2.2. Sztuczna } \\
\text { - obiekty antropoge- } \\
\text { niczne }\end{array}$ & $\begin{array}{l}\text { 1. Zewnętrzne (inne ze- } \\
\text { wnętrzne systemy róż- } \\
\text { nych poziomów hierar- } \\
\text { chicznych) } \\
\text { 2. Wewnętrzne (terytorial- } \\
\text { nie wyodrębniona war- } \\
\text { stwa podłoża materialne- } \\
\text { go, naturalnego i sztucz- } \\
\text { nego) }\end{array}$ & $\begin{array}{l}\text { 1. Morfogenetyczne } \\
\text { 2. Systemotwórcze (funkcjo- } \\
\text { nalne) } \\
\text { 2.1. działania społeczne } \\
\text { 2.2. działania transfor- } \\
\text { macyjne } \\
\text { 2.3. relacje przyrodniczo- } \\
\quad \text {-ekologiczne } \\
\text { 3. Działalności } \\
\text { 3.1. ekonomiczna } \\
\text { 3.2. kulturowa } \\
\text { 3.3. polityczna } \\
\text { 4. Złożoności } \\
\text { 4.1. między jednostkami } \\
\text { 4.2. między podsystemami } \\
\text { 4.3. między systemami } \\
\text { 5. Relacje pierwotność/wtór- } \\
\text { ność }\end{array}$ \\
\hline
\end{tabular}

Źródło: J. Parysek, Wprowadzenie do gospodarki przestrzennej, WN UAM Poznań, Poznań 2005.

Strukturę systemu określają różnego rodzaju relacje, jakie dotyczą elementów systemu, a także tych elementów i otoczenia. Chojnicki ${ }^{22}$ wyróżnia różne kategorie relacji, w tym: 1) tworzące system i określające poziom jego

${ }^{21}$ Ibidem; J. Parysek, Wprowadzenie do gospodarki.

${ }^{22}$ Z. Chojnicki, Koncepcja. 
integralności (także morfologię), 2) relacje systemotwórcze (relacje i działania społeczne, relacje i działania transformacyjne, oddziaływania przyrodniczo-ekologiczne, będace relacjami wiążącymi oraz przestrzenne relacje niewiążące), 3) działalność (ekonomiczna, kulturowa, polityczna), 4) relacje złożoności (między jednostkami ludzkimi, między podsystemami, między systemami), oraz 5) relacje pierwotne i wtórne.

Charakteryzując terytorialny system, społeczny zwrócić należy uwage na trzy bardzo istotne jego właściwości, a mianowicie: położenie, granice oraz „terytorialność”. Położenie rozpatrywać można w kilku aspektach. Dla systemu terytorialnego miasta zasadnicze znaczenie ma położenie geograficzne, które decyduje o cechach warstwy podłoża materialnego i ma znaczący wpływ na strukturę systemu. To przecież przekształcenia zależnych od położenia geograficznego, przyrodniczych składników podłoża materialnego sa jedną z podstawowych dziedzin działalności ludzkiej, określającą w poważnym stopniu warstwę społeczną systemu. Ważne jest także położenie geopolityczne, które oddziaływać może jako bariera, względnie jako czynnik rozwoju systemu (np. położenie nadgraniczne). W bardziej znaczący dla miasta sposób oddziałuje jednak, jak się wydaje, położenie konkretnego miasta w układzie społeczno-gospodarczym kraju i w układzie komunikacyjnym, powoduje bowiem określone konsekwencje w zakresie jego rozwoju gospodarczego i społecznego oraz szans rozwojowych.

Stosując podejście systemowe, pamiętać należy i o tym, a co już mimo woli zostało zasygnalizowane, że każdy system terytorialny, w tym także miasto, delimitują jego granice administracyjne. Wyznaczony przez granice, terytorialny system społeczny jest systemem terytorialnym jednak dopiero wtedy, kiedy na jego obszarze rozciaga się panowanie władzy, w warunkach polskich władzy samorządowej. To właśnie granice i władza stanowią o pewnej autonomii systemu terytorialnego i jego wewnętrznej, terytorialnej integracji. Autonomia konkretnego systemu nie jest jednak zupełna, o czym z jednej strony decyduje hierarchia systemów terytorialnych, a konkretnie nadrzędność systemów wyższego rzędu nad systemami niższego rzędu (państwa, regionu i powiatu nad miastem), z drugiej zaś - postępujący proces integracji międzynarodowej, będacy wynikiem członkostwa Polski w Unii Europejskiej.

Jak to już uprzednio napisano, miasto jako jednostka przestrzenna spełnia, jak się wydaje, warunki ku temu, aby mogło zostać potraktowane, jako terytorialny system społeczny. Jest to jednak system specyficzny, w wysokim stopniu bowiem złożony, z wyraźną dominacją elementów antropogenicznych oraz bardzo dynamiczny, jeśli idzie o funkcjonowanie i rozwój. Cechą charakterystyczna miasta jako systemu terytorialnego jest ponadto kontrola terytorium miejskiego przez ludność zamieszkująca w danym mieście ${ }^{23}$. Kontrola teoretycznie efektywna, choć praktycznie różna, z uwagi na nie najlepsze relacje władz miejskich i mieszkańców. W tego rodzaj relacjach ciagle widoczny jest model rządzenia czy zarządzania (government), a nie współrządzenia czy współzarządzania (governance).

\footnotetext{
${ }^{23}$ Ibidem. L. Mierzejewska, Rozwój zrównoważony.
} 
System terytorialny miasta tworza: zbiorowość ludzi wraz z ich potrzebami, dążeniami i życiowymi aspiracjami oraz warstwa podłoża materialnego, ze wszystkimi elementami, zarówno przyrodniczymi, jak i przede wszystkim antropogenicznymi, wyodrębniona w postaci terytorium. Wymienione składniki charakteryzuje wysoki stopień złożoności oraz liczne wewnętrzne zależności. W ramach systemu terytorialnego miasta, podobnie jak każdego innego systemu, wyróżnić można charakterystyczne jego podsystemy, takie jak: społeczny, przyrodniczy i gospodarczy. Składnikami podsystemu społecznego będą zarówno poszczególne jednostki ludzkie, jak również grupy ludzi, organizacje i inne struktury społeczne oraz instytucje funkcjonujące w mieście wraz z bazą materialna ich działania i siecią powiązań. Na podsystem przyrodniczy miasta składają się poszczególne elementy środowiska przyrodniczego, a także relacje między tymi elementami, które tworzą na obszarze miasta określone warunki życia (ekologiczne), ale także warunki gospodarowania. Składnikami podsystemu gospodarczego będą natomiast różnego rodzaju podmioty gospodarcze wraz z materialna bazą ich działania, prowadzące na obszarze miasta działalność gospodarcza, powiązane relacjami, zarówno między soba, jak i z pozostałymi podsystemami miasta oraz z otoczeniem. Relacje te określają funkcjonowanie miasta, w tym także jego gospodarkę ${ }^{24}$.

Otoczenie terytorialnego systemu społecznego miasta rozpatrywać można $\mathrm{w}$ aspekcie wewnętrznym i zewnętrznym. W aspekcie wewnętrznym jest to środowisko przyrodnicze, które jest przedmiotem oddziaływania i oddziałuje na zbiorowość ludzi wchodzących w skład danego systemu społecznego, a w aspekcie zewnętrznym - inne terytorialne systemy społeczne, z którymi dany system jest powiązany wzajemnymi oddziaływaniami ${ }^{25}$.

Miasto, jako system, tworzą zarówno elementy przyrodnicze, jak i antropogeniczne (sztuczne), które ten system konstytuuja, ale i otaczają (jako składniki otoczenia). Jest oczywiste, że charakter i zakres oddziaływania na siebie elementów systemu miasta zmienia się w czasie. Dzieje się to w efekcie oddziaływań zachodzących między społeczeństwem a przyrodą, co w przypadku miasta oznacza przekształcanie elementów przyrodniczych w antropogeniczne. W konsekwencji tego procesu środowisko miejskie jest w coraz większym stopniu sztucznym (antropogenicznym). Ponadto charakteryzuje się bardzo dużą dynamiką funkcjonowania i rozwoju, która przyhamować mogą jedynie sytuacje kryzysowe i z czymśs takim mamy aktualnie do czynienia w przypadku polskich miast, choć nie tylko polskich.

Terytorialny system społeczny miasta, przez wyznaczone granice, jest w pewnym sensie oddzielony od otoczenia zewnętrznego, którymi sa inne terytorialne systemy społeczne. Nie jest to jednak izolacja całkowita, choćby ze względu na to, że miasta, aby należycie funkcjonować, wymagaja pewnego „zasilania zewnętrznego", czyli odpowiedniego ukształtowania relacji zewnętrznych. Wymagaja przede wszystkim dostaw energii, paliw, surowców, żywności itd.

\footnotetext{
${ }^{24}$ L. Mierzejewska, Rozwój zrównoważony.

25 Z. Chojnicki, Koncepcja; L. Mierzejewska, Rozwój zrównoważony.
} 
i dlatego też nie mogą właściwie funkcjonować, a niekiedy nawet istnieć bez związków z otoczeniem. Wydaje się, że rola otoczenia zewnętrznego rośnie wraz ze wzrostem wielkości i rangą miasta w systemie osadniczym, co z jednej strony jest związane $\mathrm{z}$ poszerzaniem zakresu pełnionych funkcji (wzrostem poziomu centralności), a z drugiej - z rosnącym zapotrzebowaniem na różnego rodzaju zasoby pochodzące $\mathrm{z}$ otoczenia miasta. Relacje zewnętrzne w systemu miasta są także często warunkowane koniecznością usuwania z miasta i utylizacji odpadów ${ }^{26}$.

Istotą terytorialności systemu miasta jest władza (samorządowa), której działanie przejawia się m.in. w kontrolowaniu obszaru miejskiego. Czyni to zbiorowość mieszkańców, a konkretnie ich reprezentacja, czyli samorządowe władze miejskie ${ }^{27}$. Z kwestią efektywnego kontrolowania terytorium miasta przez tę zbiorowość wiąże się, w pewnym stopniu, problem granic. Pozornie wydaje się, że miasta mają wyraźnie określone granice (arytmomorficzne). W świetle nowszych wyników badań przyjąć jednak należy taki punkt widzenia, który zakłada pewną płynność, „rozmycie” czy poszerzanie się realnych granic, co jest widoczne zwłaszcza w przypadku postępującego procesu suburbanizacji ${ }^{28}$.

Warto w tym miejscu podkreślić, że w warunkach polskich, choć nie tylko polskich, zakres kontroli i odpowiedzialności władz dotyczy wyłącznie obszaru znajdującego się w granicach miasta. W świecie spotyka się jednak i takie sytuacje, w których obok struktur władzy lokalnej, której uwaga skoncentrowana jest na problemach samego miasta, funkcjonują struktury zarządzania, planowania i koordynacji rozwoju, obejmujące zasięgiem działania, obszary całych aglomeracji. Działanie to dotyczy kształtowania organizacji, struktury i funkcjonowania takich podsystemów aglomeracji, jak: układ dróg, komunikacja publiczna, system wodociagowy i kanalizacyjny, system ogrzewania, ochrona zdrowia, edukacja na wyższych poziomach, bezpieczeństwo osób i mienia, ratownictwo itp. W gestii takiej struktury pozostają także planowanie przestrzenne i gospodarka przestrzenna oraz ochrona środowiska. Sytuacja, z jaka mamy do czynienia w Polsce, i istniejące rozwiązania organizacyjno-prawne nie uwzględniaja jednak procesu kształtowania się aglomeracji miejskich, czego głównym sprawca jest miasto, jako autonomiczna jednostka terytorialna, a konkretnie jego rozwój i pełnione funkcje ${ }^{29}$. Paradoksalność tej sytuacji podkreśla fakt, że to miasto ponosi właściwie wszystkie konsekwencje rozwoju aglomeracji i procesu suburbanizacji, w związku z czym nie może być

26 Ibidem.

27 Z. Chojnicki, Koncepcja.

${ }^{28}$ E. Soja, The Political Organization of Space, Commission on College Geography, Res. Paper, 1971.8; S. Gale, M. Atkinson, On the Set Theoretical Foundation of the Regionalization Problem, w: S. Gale, G. Olson (red.), Philosophy in Geography, D. Reidel, Dordrecht 1979; M. Atkinson, Developing Indicators of Sustainable Development: Lessons from Sustainable Seattle, „Environment Impact Assessment Review” 16, 1996, s. 337-350.

${ }_{29}$ J. Parysek, Aglomeracje miejskie, w: W. Maik (red.), Aglomeracje w Polsce na przełomie XX i XXI wieku. Problemy rozwoju, przekształceń strukturalnych i funkcjonowania, Wyższa Szkoła Gospodarki w Bydgoszczy, Bydgoszcz 2009, s. 31-54. 
efektywnym generatorem rozwoju, nie tylko aglomeracji, ale i całego regionu, którego jest ośrodkiem węzłowym, boryka się ponadto z problemami natury finansowej ${ }^{30}$.

Terytorialny system społeczny miasta, jak każdy inny system, konstytuuja różnego rodzaju relacje, wiążące podstawowe jego składniki, a także podsystemy. Jednocześnie relacje te określają strukturę systemu oraz stopień jego domknięcia (otwarcia). System miasta opisuja dodatkowo także relacje niewiążące (skalarne), które nie maja jednak charaktery systemotwórczego.

Relacje wiążące (wektorowe), czyli systemotwórcze, w terytorialnym systemie społecznym miasta podzielić można na $\left.{ }^{31}: 1\right)$ relacje i działania społeczne, zachodzące między ludźmi, zbiorowościami ludzkimi lub podsystemami społecznymi występującymi w mieście, 2) relacje transformacyjne, polegające na przekształcaniu przez mieszkańców miast i podmioty funkcjonujące w mieście środowiska przyrodniczego lub obiektów materialnych (sztucznych) w obiekty o charakterze użytkowym, czyli na wykonywaniu pewnej pracy oraz 3) oddziaływania przyrodniczo-ekologiczne, obejmujące oddziaływania środowiska przyrodniczego na ludzi i ich działalność. Do relacji niewiążących zaliczane są natomiast relacje przestrzenne, które dotycza położenia i wzajemnych odległości elementów tworzacych system. Ma to szczególne znaczenie w przypadku terytorialnego systemu społecznego miasta, gdzie zagospodarowanie przestrzenne wpływa na kształtowanie relacji wiążących w systemie, i to zarówno relacji społecznych (np. przestrzenie publiczne umożliwiające kontakty społeczne), jak i transformacyjnych (np. tereny przeznaczane pod określony typ zagospodarowania) czy przyrodniczo-ekologicznych (np. konflikty przestrzenne).

Dużą rolę w codziennym funkcjonowaniu, a zatem i określaniu, w pewnym sensie, warunków równowagi terytorialnego systemu społecznego miasta odgrywaja jednak relacje z otoczeniem, zarówno swoistym (inne systemy terytorialne), jak i nieswoistym (środowisko przyrodnicze). Relacje te generalnie pomagaja $\mathrm{w}$ utrzymaniu terytorialnego systemu społecznego miasta $\mathrm{w}$ stanie pewnej równowagi dynamicznej, jednak mogą także stać się źródłem perturbacji, wytrącającej ten system ze tego właśnie stanu (np. brak dostaw energii, kryzys finansowy w innym kraju, wojna, katastrofa ekologiczna). Złożoność relacji zachodzących pomiędzy miastem i otoczeniem zwiększa dodatkowo dynamikę zmian zachodzaçcych $\mathrm{w}$ terytorialnym systemie miasta, traktowanym całościowo ${ }^{32}$.

Sprawczą rolę w kształtowaniu wszystkich relacji terytorialnego systemu społecznego miasta, a tym samym w określaniu sposobu, efektywności i stabilności czy równowagi funkcjonowania systemu miasta, jako całości, odgrywają mieszkańcy miasta. To właśnie działania ludzkie kształtują podstawowe kategorie relacji systemowych, tj. ekonomiczne, kulturowe i polityczne ${ }^{33}$.

${ }^{30}$ J. Parysek, Rozwój miast a polityka miejska; idem, Urban Development Policy.

${ }^{31}$ Z. Chojnicki, Wspótczesne problemy gospodarki przestrzennej, „Biuletyn KPZK PAN” 1990, nr 146, s. 203-219; idem, Koncepcja terytorialnego systemu społecznego, w: T. Czyż (red.), Podstawy metodologiczne i teoretyczne geografii, Bogucki Wydawnictwo Naukowe, Poznań 1999.

${ }^{32}$ Ibidem. L. Mierzejewska, Rozwój zrównoważony.

${ }^{33}$ Z. Chojnicki, Koncepcja. 
We współczesnym świecie niektóre oddziaływania zachodzące w systemie miasta związane są z wpływem społeczeństwa na środowisko przyrodnicze. Środowisko zaś w postaci sprzężenia zwrotnego oddziałuje na warunki i sposoby gospodarowania w mieście i na warunki egzystencji mieszkańców. Choć zakres i siła oddziaływania środowiska przyrodniczego na mieszkańców miasta maja w zasadzie charakter ponad systemowy (wykraczaja poza granice konkretnego terytorialnego systemu społecznego), to jednak charakter tego oddziaływania może być nie tylko zróżnicowany, ale i kontrolowany oraz modyfikowany. Będzie to jednak przede wszystkim zależne od właściwości i kondycji podsystemu ekonomicznego. Kontrola oddziaływania oraz możliwości dokonywania modyfikacji i zmian zależeć zaś w dużej mierze będą od poziomu techniki, kultury, zamożności (bogactwa), a także od organizacji społeczności miejskiej. Miasta bogatsze, majace lepszy (bardziej realny ze względów finansowych) dostęp do nowoczesnych technologii, mieć będą większe szanse na ograniczenie niekorzystnych oddziaływań człowieka na środowisko i przekształconego środowiska przyrodniczego na ludzi niż miasta ubogie. Wysoki poziom rozwoju gospodarczego, stosowanie zaawansowanych technologii, a przede wszystkim zasobność kasy miejskiej tworzą realną szansę na poprawę relacji ekologicznych w terytorialnym systemie społecznym miasta ${ }^{34}$.

Zakres transformacji obiektów materialnych w terytorialnym systemie społecznym miasta, zarówno przyrodniczych, jak i sztucznych, zależy od rodzaju wykonywanej na obszarze miasta pracy. Jest to najczęściej praca produkcyjno-materialna, kulturalna lub kierowniczo-organizacyjna ${ }^{35}$. Szczególna rola w kształtowaniu właściwych relacji w systemie miasta przypada jednak chyba, jak się wydaje, pracy kierowniczo-organizacyjnej, polegajacej na planowaniu, kierowaniu, zarządzaniu i kontrolowaniu działalności ludzi, w szczególności w zakresie działalności produkcyjno-materialnej ${ }^{36}$.

Relacje wewnątrz systemowe (w systemie miasta, jako całości) i międzysystemowe (między podsystemami systemu miasta), a także relacje terytorialnego systemu miasta z otoczeniem (relacje zewnętrzne) muszą być zatem kształtowane tak, aby gwarantowały stabilność całego systemu. Osiagnięcie takiego stabilnego stanu jest jednak bardzo trudne, przede wszystkim ze względu na dużą dynamikę zmian zachodzących w tak złożonym i dynamicznym systemie, jakim jest terytorialny system społeczny miasta ${ }^{37}$.

\section{Miasto jako ekosystem}

Miasto traktować można nie tylko jako terytorialny system społeczny, lecz także jako ekosystem. Wydaje się jednak, że taki system (ekosystem miasta), biorąc pod uwagę charakterystyczne jego cechy, można w zasadzie uznać za pewną kategorię terytorialnego systemu społecznego.

\footnotetext{
34 Ibidem.

35 Por. L. Krzyżanowski, Podstawy nauki zarzadzania, PWN, Warszawa 1985.

${ }^{36}$ L. Mierzejewska, Rozwój zrównoważony.

37 Ibidem.
} 
Pojęcie ekosystemu oraz podstawowe procesy i interakcje tam zachodzace przenoszone sa często $\mathrm{z}$ ekologii na inne dziedziny nauki, w tym przede wszystkim na nauki społeczne (ekologia społeczna, ekologia człowieka). Poglądy wspomnianej już uprzednio tzw. socjologicznej szkoły chicagowskiej sa tego najlepszym przykładem. Skoro traktuje się miasto jako ekosystem, na podstawie analogii do zjawisk zachodzących w przyrodzie, podejmuje się próby opisania funkcjonowania jednostek i społeczności ludzkich. Pojęcia zaczerpnięte z ekologii wykorzystywane się często także do zjawisk gospodarczych (np. sukcesja usług, funkcji czy konkurencja). Kwestią pozostaje jednak zawsze to, czy i w jakim stopniu potraktowanie miasta jako ekosystem otwiera nowe spojrzenie na naturę, organizację, strukturę i funkcjonowania miasta ${ }^{38}$.

Aby dany system można było nazwać ekosystemem, musi on spełnić określone warunki, do których przede wszystkim należy nierozłączne powiązanie ze sobą i wzajemne oddziaływanie organizmów żywych i nieożywionego środowiska. Tak bowiem jest od wieków, że żaden żywy organizm nie może istnieć samodzielnie, tj. bez środowiska. Także i żaden system nie może funkcjonować bez środowiska (otoczenia) zewnętrznego. W systemie środowiska (ekosystemie) musi także istnieć przepływ energii, prowadzacy do ${ }^{39}:$ 1) powstania wyraźnie określonej struktury troficznej (łańcuchy pokarmowe), 2) zróżnicowania biotycznego (komponent autotroficzny i heterotroficzny) oraz 3) krążenia materii (tj. wymiany pierwiastków i związków między żywymi i nieożywionymi częściami ekosystemu). O pewnym układzie jako ekosystemie można mówić jednak dopiero wtedy, kiedy podstawowe składniki występują i działaja wspólnie, osiagając choćby krótkotrwała stabilność funkcjonalną ${ }^{40}$.

Ekosystemy można badać pod różnym kątem i na różne sposoby. Z funkcjonalnego punktu widzenia systemy te bada się jednak przede wszystkim ze względu na: 1) przepływ energii, 2) łańcuchy pokarmowe, 3) obieg wody, 4) krążenie składników mineralnych, 5) rozwój i ewolucję, 6) modele zróżnicowania w czasie i przestrzeni oraz 7) sterowanie.

Wielu autorów prezentuje pogląd, że miasto jest układem ekologicznym (ekosystemem) wytworzonym i całkowicie zdominowanym przez człowieka, którego działalność wywiera głęboki wpływ zarówno na sferę biotyczna, jak i abiotyczną miasta. Oczywiście miasto jest także środowiskiem życia mieszkańców miasta (osobników), którzy w tym ekosystemie zajmują szczególna pozycję. Jednocześnie miasto wydaje się takim systemem, w którym obieg materii dokonuje się w specyficzny sposób, a energia przepływa w sposób często niepodobny do ekosystemów naturalnych. Charakterystyczne jest bowiem to, że miasto podstawowe źródła energii, tj. energię elektryczna, paliwa i żywność (pokarm) importuje często z terenów zewnętrznych. Produkt przemian energetycznych miasta ulega jednak w dużej mierze rozproszeniu, choć w części, w postaci odpadów, powraca do otoczenia zewnętrznego, ponieważ jest wy-

38 Por. ibidem.

39 E. Odum, Podstawy ekologii, Państwowe Wydawnictwo Rolnicze i Leśne, Warszawa 1982.

${ }^{40}$ Por. ibidem. A. Macias, Badanie przepływów materii i energii w krajobrazie miejskim. Klasyfikacja krajobrazu. Teoria i praktyka, „Problemy Ekologii Krajobrazu” 20, 2008, s. 243-250; L. Mierzejewska, Rozwój zrównoważony. 
wożony poza obszar miasta. Jest oczywiste, że zapotrzebowanie energetyczne miasta jest bardzo duże i zależy przede wszystkim od liczby mieszkańców i ich zamożności, struktury wieku, poziomu cywilizacyjno-kulturowego, struktury gospodarki, poziomu rozwoju gospodarczego, poziomu i struktury konsumpcji, powiązań kooperacyjnych, pełnionych funkcji, poziomu rozwoju kulturowego, układu przestrzennego, intensywności zagospodarowania itp. Rola miejskich obszarów rolniczych w bilansie pokarmowym miasta jest niewielka, z uwagi na mały odsetek gruntów będących w użytkowaniu rolniczym. Z tego samego powodu niewielka jest także rola takich ekosystemów miejskich, jak parki, ogrody, zespoły leśne czy łąki, które pełnią przede wszystkim rolę przestrzeni publicznych o funkcjach rekreacyjnych. W bilansie energetycznym miasta mało znaczącą rolę odgrywa też utylizacja wytwarzanych odpadów, które zazwyczaj wywozi się poza miasto. W polskich miastach nie ma raczej biogazowni, wykorzystujacych odpady komunalne, podobnie jak spalarni śmieci, dostarczających energii elektrycznej i cieplnej ${ }^{41}$.

Ze względu na specyfikę obiegu materii i przepływu energii nie ma jednoznacznego stanowiska co do tego, czy miasto (jako całość) można jednoznacznie potraktować tak jak ekosystem, czy też nie. Zdaniem niektórych ekologów, niepełność składu gatunkowego w mieście, zwłaszcza zaś producentów, uzależnia miasto od zewnętrznych dostaw energii, co powoduje zerwanie łańcucha troficznego i zakłócenia w przepływie energii ${ }^{42}$. Skład gatunkowy miasta, traktowanego jako ekosystem, tworzą nie tylko pojedyncze osoby, ale także grupy społeczne, podmioty gospodarcze, instytucje, także populacje zwierząt i roślin, między którymi dokonuje się jednak, choć specyficzny, przepływ energii i materii. Inne osoby nie mają jednak wątpliwości co do tego, że miasto jest całościowym układem strukturalno-funkcjonalnym, który składa się z elementów biotycznych oraz abiotycznych środowiska, w którym także zachodza procesy obiegu materii i przepływu energii, a więc że jest ekosystemem ${ }^{43}$.

Nieco inny, wydaje się jednak, że bardziej radykalny punkt widzenia na ekosystem miasta, zaprezentowała znana urbanistka amerykańska J. Ja$\operatorname{cobs}^{44}$, sugerujac, że miejskie budynki, ulice, osiedla itp. funkcjonują w sumie tak, jak dynamiczny organizm, zmieniajacy się w reakcji na działania podejmowane przez ludzi. Uważała także, że te właśnie elementy miasta współdziałają ze sobą wzajemnie (synergicznie), analogicznie do naturalnych ekosystemów. Relacje i procesy zachodzace w ekosystemach naturalnych zamienia na aspekty społeczno-gospodarcze funkcjonowania miasta - i to różni prezentowany przez Jacobs punkt widzenia od stanowiska przyrodników i ekologów. Takie postrzeganie miasta (ekosystem) umożliwiło urbanistom i architektom przyjąć tę prawdę, że sposób zagospodarowania przestrzennego miasta ma swoje konsekwencje w funkcjonowaniu całego systemu miasta. Pomogło po-

41 Ibidem.

42 B. Jackowiak, Miasto jako układ ekologiczny, w: Kompendium wiedzy o ekologii, PWN, Warszawa-Poznań 1999; L. Mierzejewska, Rozwój zrównoważony.

${ }^{43}$ H. Zimny, Uwarunkowania ekologiczne i funkcjonowanie przyrody miasta, w: Środowisko przyrodnicze Warszawy, PWN, Warszawa 1990; L. Mierzejewska, Rozwój zrównoważony.

${ }_{4}$ J. Jacobs, The Death and Life of Great American Cities, Random House and Vintage Books, New York 1961. 
nadto znaleźć sposoby na poprawę efektywności jego funkcjonowania, przez zmianę układu pewnych elementów tego systemu. Efektywności, której wyrazem jest poprawa warunków i jakości życia oraz poziomu obsługi mieszkańców $^{45}$. Podobny do przedstawionego, punkt widzenia reprezentują zwolennicy tzw. ekosystemów architektonicznych utworzonych przez elementy antropogeniczne (architektura) i przyrodnicze. Systemowość tego podejścia sprawia, że wyróżniane są nowe, symbiotyczne układy o właściwościach przewyższających prostą sumę cech poszczególnych składników (żaden system, jako funkcjonalna całość nie jest prostą sumą tworzących ten system elementów). Ważne dla takich systemów jest efektywne zintegrowanie zabudowy i środowiska w krajobrazie miejskim. Chodzi zatem o to, aby w kształtowanych w tym podejściu strukturach przestrzenno-funkcjonalnych miasta zespoły mieszkaniowe wtopione były w środowisko przyrodnicze, obiekty turystyczne sasiadowały z lasami i jeziorami itp. Zespoły parkowe i ogrody będą natomiast ekosystemami o szczególnej różnorodności i kompozycji, podczas gdy obiekty użyteczności publicznej będą przykładami tzw. bioarchitektury o walorach kulturowych. Wprowadzanie ekosystemów architektonicznych wymaga jednak przyjęcia nowych rozwiązań w sferze projektowej, organizacyjnej, a także finansowej ${ }^{46}$.

Choć niektóre z zaprezentowanych modeli różnią się od klasycznego modelu ekosystemu, to jednak wszystkie one pozwalają lepiej i pełniej zrozumieć organizacje, strukturę i funkcjonowanie miasta (jako ekosystemu). Pozwalaja jednocześnie określić zakres, w jakim działalność człowieka wpłynąć może na kształtowanie struktury przestrzennej miasta i na efektywność jego funkcjonowania ${ }^{47}$. Postrzeganie miasta jako ekosystemu wydaje się szczególnie ważne w sytuacji, gdy tempo urbanizacji jest szybsze niż inne procesy zachodzące w środowisku człowieka. Spojrzenie na miasto jako na układ ekologiczny, będacy w istocie rzeczy środowiskiem życia mieszkańców, pozwala jednak dostrzec to, że współczesnym problemem jest nie tylko wyczerpywanie się zasobów przyrody i utrata bioróżnorodności, ale także pogarszanie się jakości przestrzeni życiowej człowieka w mieście ${ }^{48}$.

\section{Miasto jako organizm: organicystyczna koncepcja miasta}

Przyjęcie systemowego modelu organizacji, struktury i funkcjonowania miasta oznaczać może w ujęciu modelowym potraktowanie tej jednostki osadniczej jako czegoś na kształt organizmu żywego, przy pełnej świadomości antropogenicznej natury samego miasta Oczywiście w ujęciu systemowym możliwe jest także przyjęcie modelu mechanistycznego, jednak natura miasta jest tego rodzaju, że jego rozwój i funkcjonowanie bardziej podobne są do życia organizmu niźli do działania mechanizmu, na co już zwracano uwagę.

\footnotetext{
${ }^{45}$ L. Mierzejewska, Rozwój zrównoważony.

${ }^{46}$ W. Pęski, Zarzadzanie zrównoważonym rozwojem miast, Arkady, Warszawa 1999; L. Mierzejewska, Rozwój zrównoważony.

47 Ibidem.

${ }^{48}$ E. Odum, op. cit.; L. Mierzejewska, Rozwój zrównoważony.
} 
Organicystyczną koncepcję miasta łączy się z nazwiskiem F. Ratzla, niemieckiego zoologa, geografa i etnografa ${ }^{49}$. Koncepcja ta nie miała jednak swojego osadzenia w sformułowanej znacznie później przez Bertalanffy'ego ${ }^{50}$ ogólnej teorii systemów. Analogii między miastem a organizmem doszukiwało się wielu innych badaczy, zwracając uwagę na podobieństwo procesów toczących się w mieście i procesów, jakie zachodzą w organizmie żywym ${ }^{51}$. Tabela 3 wskazuje na tego rodzaju, możliwe do zaakceptowania analogie, jakkolwiek trudno w tym przypadku mówić o systemowym potraktowaniu miasta jako całości. Wydaje się jednak, że potraktowanie miasta tak jak organizm jest ze wszech miar uprawnione, jednostka ta bowiem, jako funkcjonalna całość (system), spełnia wszystkie warunki konieczne czy też posiada cechy, jakie spełniać (posiadać) musi organizm żywy ${ }^{52}$.

\section{Tabela 3}

Miasto a organizm żywy (podstawowe analogie)

\begin{tabular}{|l|l|}
\hline \multicolumn{1}{|c|}{ Organizm żywy } & \multicolumn{1}{c|}{ Miasto } \\
\hline układ krwionośny (cyrkulacja krwi) & ruch uliczny, transport \\
\hline odżywianie & dostawy energii i materii (dóbr) \\
\hline trawienie & wykorzystanie energii i materii \\
\hline metabolizm & przemiana materii (produkcja dóbr i usług) \\
\hline system nerwowy & przepływ informacji \\
\hline mózg & zarządzanie, wiedza, technologia \\
\hline zmysły & odbieranie informacji, percepcja \\
\hline wydalanie & wytwarzanie i składowanie odpadów (utylizacja) \\
\hline
\end{tabular}

Źródło: J. Parysek, L. Mierzejewska, Życie miasta. Studium Poznania. Miasto i jego mieszkańcy, Bogucki Wydawnictwo Naukowe, Poznań 2013.

T. Ganti ${ }^{53}$ wyróżnia 5 cech koniecznych i 3 cechy potencjalne, którymi musi się charakteryzować obiekt uznany za organizm (także za system żywy). Do cech koniecznych zaliczył: 1) całościowy i jednostkowy charakter, czyli wyodrębnienie ze świata zewnętrznego, 2) metabolizm, 3) homeostazę, czyli utrzymanie stanu wewnętrznej równowagi, 4) podsystem przechowywania i przetwarzania informacji, ważny dla funkcjonowania, 5) wewnętrzny system regulacji funkcjonowania ${ }^{54}$. Wyróżnionymi cechami potencjalnymi sa

${ }^{49}$ W. Maik, op. cit.

${ }^{50}$ L. von Bertalanffy, An Outline; idem, General System Theory; idem, Historia rozwoju.

${ }^{51}$ H. Haken, Synergetic as a Theory of Creativity and Its Planning, w: A. E. Andersson et al. (red.), The Cosmo-creative Society: Logistical Networks in Dynamic Economy, Springer Verlag, Berlin 1993.

52 T. Ganti, Podstawy życia, WP, Warszawa 1986.

53 Ibidem.

${ }^{54}$ Ibidem; J. Parysek, L. Mierzejewska, Życie miasta. Studium Poznania. Miasto. 
natomiast: 1) zdolność wzrostu i rozmnażania, 2) zmienność w replikacji, czyli ewolucja, oraz 3) śmiertelność.

Analiza charakteru cech koniecznych pozwala stwierdzić, że definiują one przede wszystkim organizm żywy, cechy potencjalne zaś odnoszą się raczej do procesów życiowych ${ }^{55}$. Są to jednak cechy ważne, kiedy miasto zamierzamy potraktować jako organizm, czyli system żywy (tab. 4).

\section{Tabela 4}

Miasto jako obiekt spełniający warunki konieczne organizmu żywego

\begin{tabular}{|c|c|}
\hline Warunki konieczne & Odniesienie warunków koniecznych do miasta \\
\hline $\begin{array}{l}\text { 1. Całościowy i jednostkowy } \\
\text { charakter, czyli wyodrębnienie } \\
\text { ze świata zewnętrznego }\end{array}$ & $\begin{array}{l}\text { 1. Miasto jest wyodrębniona z otoczenia jednostka } \\
\text { osadnicza, choć w przypadku współczesnych miast } \\
\text { zacierają się granice z otoczeniem; jest także wyod- } \\
\text { rębnioną jednostką terytorialnego podziału kraju; } \\
\text { ma zatem charakter jednostkowy }\end{array}$ \\
\hline 2. Metabolizm & $\begin{array}{l}\text { 2. Na obszarze miasta dokonuje się przemiana mate- } \\
\text { rii i energii, choć proces metabolizmu sprowadzić } \\
\text { można do zasilania finansowego składników syste- } \\
\text { mu miasta, gwarantującego funkcjonowanie miasta } \\
\text { i jego rozwój }\end{array}$ \\
\hline $\begin{array}{l}\text { 3. Homeostaza, czyli utrzymanie } \\
\text { stanu wewnętrznej równowagi }\end{array}$ & $\begin{array}{l}\text { 3. Homeostaza jest stan równowagi funkcjonalnej sy- } \\
\text { stemu miasta, warunkowany przez funkcjonowanie } \\
\text { służb miejskich }\end{array}$ \\
\hline $\begin{array}{l}\text { 4. Podsystem przechowywania } \\
\text { i przetwarzania informacji, } \\
\text { ważny dla funkcjonowania }\end{array}$ & $\begin{array}{l}\text { 4. Służby miejskie, które celem właściwego funkcjono- } \\
\text { wania, gromadzić i przechowywać muszą informacje }\end{array}$ \\
\hline $\begin{array}{l}\text { 5. Wewnętrzny system regulacji } \\
\text { funkcjonowania }\end{array}$ & $\begin{array}{l}\text { 5. System ten tworza władze miejskie i ich agendy, } \\
\text { zrządzając funkcjonowaniem i rozwojem miasta } \\
\text { przy wykorzystaniu środków prawnych, administra- } \\
\text { cyjnych, ekonomiczno-finansowych, organizacyjno- } \\
\text {-technicznych i innych }\end{array}$ \\
\hline
\end{tabular}

Źródło: J. Parysek, L. Mierzejewska, Życie miasta. Studium Poznania. Miasto i jego mieszkańcy, Bogucki Wydawnictwo Naukowe, Poznań 2013.

Mimo rozlewania się miasta na zewnątrz i nie zawsze pełnej zgodności obszaru intensywnej zabudowy z granicami administracyjnymi, miasto ma jednak, mimo wszystko, charakter jednostkowy, który utrwalają: status jednostki terytorialnego podziału kraju oraz przestrzenny zakres kompetencji samorzadu terytorialnego (rady miejskiej). Wraz z postępująca suburbanizacją zaciera się jednak fizjonomiczna granica między miastem a obszarem zewnętrznym, na co już uprzednio zwracano uwagę.

55 W. J. H. Kunicki-Goldfinger, Podstawy biologii, PWN, Warszawa 1978; A. Horst, Ekologia człowieka, WP, Warszawa 1976; T. Ganti, op. cit. 
W mieście, tak jak w każdym żywym organizmie, dokonuje się przemiana materii i energii, jakkolwiek ma ona specyficzny charakter. Miasto jako jednostka terytorialna oraz jego mieszkańcy zużywaja, co jest oczywiste, różnego rodzaju energię, np. elektryczna, gazowa, cieplną, oraz różnego rodzaju materię, np. węgiel, drewno, szkło, papier, żywność, odzież i in., co można potraktować, jako pewną formę metabolizmu. Jednak na metabolizm miasta składają się także przepływy kapitałowe, wiedzy, umiejętności, różnych wzorców, informacji itp. Tak opisana przemiana materii może w konkretnych sytuacjach i warunkach ulec pewnym zakłóceniom. Mimo to można jednak mówić o takich procesach, które identyfikować należy z metabolizmem miejskim.

Podobnie ma się rzecz z homeostaza. Miasto, aby właściwie funkcjonować, wykazywać musi stan równowagi składających się na miasto elementów. Stan niezakłóconego funkcjonowania miasta oraz zrównoważenia jego struktur można zatem identyfikować z homeostaza, którą gwarantują procesy metaboliczne, a konkretnie zrównoważone działania elementów systemu miasta, zwłaszcza służb komunalnych

Trudno sobie wyobrazić niezakłócone funkcjonowanie miasta bez systemu kompletowania, przetwarzania, przechowywania i wykorzystywania informacji. Jest to jedno z podstawowych zadań organów wykonawczych samorząów miejskich (struktur administracyjnych miasta).

Miasto jest systemem teleologicznym. Funkcjonuje po to, aby zapewnić możliwie jak najlepsze warunki życia i obsługi mieszkańców. Jednocześnie jest systemem, w którym sprawczymi elementami jego funkcjonowania i rozwoju są właśnie jego mieszkańcy. Sytuacja ta oznacza, że tego rodzaju system wymaga organizacji i funkcjonowania odpowiedniego podsystemu regulacyjnego, którym jest władza miejska, a konkretnie samorząd miasta (por. tab. 4).

Przedstawiona powyżej sytuacja wyraźnie przemawia za tym, że miasto nie tylko potraktować można jako organizm, ale dalej - konsekwentnie można mówić o jego życiu. Można także pokusić się o identyfikację w mieście potencjalnych cech organizmu dokumentujacych jego procesy życiowe ${ }^{56}$. Wprawdzie miasto nie ma możliwości, traktowanego w ścisłym tego słowa znaczeniu, „rozmnażania się”, ale posiada możliwości wzrostu czy rozwoju, a także „rozlewania się" na zewnątrz. Rozwój miasta dotyczy zarówno jego szeroko rozumianej wielkości, jak i potencjału gospodarczego oraz ma charakter zarówno ilościowy, jak i jakościowy. Tak na dobrą sprawę, można także mówić o rozmnażaniu, kiedy za ten proces uzna się powstawanie nowych osiedli mieszkaniowych, centrów handlowych, a także powstawanie nowych, miejskich substruktur przestrzennych itp. W przypadku miasta można z całą pewności mówić o jego ewolucji, choć jest to nieco inna ewolucja od tej, jaka w biologii dotyczy gatunków. Stosowany w literaturze przedmiotu termin ewolucja miasta oznacza generalnie przekształcenia i dostosowanie formy organizacyjno-przestrzennej i ustrojowo-gospodarczej miasta do warunków rzeczywistości cywilizacyjno-kulturowej. Mimo stosunkowo dużej trwałości w czasie niektórych form przestrzennych miasta, ich charakter zmienia się jednak stopniowo, wraz z upływem czasu, stosownie do wyzwań zmieniającej się rzeczywistości,

\footnotetext{
56 Ibidem.
} 
zwłaszcza zaś potrzeb społeczności miejskiej. Generalne zmiany formy przestrzennej miast i ich struktur dokonywały się wraz ze zmianą epok czy okresów historycznych oraz formacji społeczno-ustrojowych. W tym kontekście można mówić o modelu miasta starożytnego (greckiego, rzymskiego), średniowiecznego, barokowego, renesansowego, feudalnego, kapitalistycznego, kolonialnego, socjalistycznego, nowożytnego, modernistycznego i in., co wskazuje na ewolucję tej najbardziej złożonej formy antropogenicznej, jako powstałej w procesie rozwoju cywilizacyjno-kulturowego. Najwięcej problemów sprawia identyfikacja z miastem tego, co w odniesieniu do organizmów żywych nazywa się śmiertelnościa. Za pewnego rodzaju śmiertelność miast niewątpliwie uznać można ich upadek, zwłaszcza w odniesieniu do takich (miast), które zniknęły z mapy współczesnego świata lub które wyraźnie straciły swoje znaczenie. Śmiertelnością miasta będzie także jego zapaść w wyniku kataklizmu, wojny czy poważnego kryzysu gospodarczego. Obserwowany obecnie proces kurczenia się miast także może zostać uznany za symptom nadchodzącej śmierci miasta, przynajmniej w jego istniejącej i rozwiniętej formie. Choć realne umieranie miast nie znajduje się dziśs na porządku dziennym, to jednak obserwowane w historii miast ich upadki oraz kurczenie się można przyjać za symptomy ciagle możliwej ich śmiertelności.

Odniesienie do miast współczesnych cech organizmu żywego i życia pozwala zatem nie tylko potraktować miasto jako organizm, ale także jako organizm żywy i żyjący, a zatem mówić o życiu miasta.

\section{IV. ŻYCIE MIASTA}

Przyjęcie organicystycznej, systemowej koncepcji miasta otwiera nowe pola badawcze, pozwalajace z jednej strony lepiej zrozumieć funkcjonowanie miasta, a z drugiej - lepiej dostosować jego infrastrukturę, jej rozmieszczenie oraz działanie do potrzeb mieszkańców. Tym nowym polem badawczym jest badanie życia miasta poprzez analizę czasowej i przestrzennej aktywności mieszkańców oraz funkcjonowanie w czasie infrastruktury miejskiej.

Większość procesów i zjawisk życiowych cechuje powtarzalność w czasie, co umożliwia optymalizacje procesów regulacyjnych ustroju i ich synchronizację ze środowiskiem zewnętrznym. W ten sposób wiele czynności życiowych okresowo zmienia swoje nasilenie. Czasu wymagają zarówno odbudowa zużytych komórek organizmu, przywrócenie sprawności zużytym mięśniom, jak i procesy trawienia i przemiany materii, jakie zachodzą w organizmie. Jest więc biologiczne celowe, aby przebieg procesów życiowych nie kolidował z realizacją innych, ważnych funkcji i zadań organizmu. Wszystko to dyktuje potrzebę synchronizacji działań organizmu w czasie. W odniesieniu do organizmu ludzkiego brak takiej synchronizacji powodowałby problemy życia społecznego (komplikowałby to życie), utrudniałby rozród, opiekę nad dziećmi itp. ${ }^{57}$ Wielu

${ }^{57}$ B. Sadowski, J. A. Chmurzyński, Biologiczne mechanizmy zachowania, PWN, Warszawa 1989. 
tym problemom zapobiega, wpisana niejako w funkcjonowanie organizmu, rytmika zjawisk biologicznych, która przyporządkowuje zmiany stanu organizmu okresowym zmianom środowiska, w jakim ten organizm funkcjonuje. Wiąże się to z poczuciem czasu i jego rozpoznawaniem, skutkiem czego życie każdego organizmu staje się rytmiczne (rytm spożywania pokarmów oraz czuwanie i sen itp.).

Tak więc rytmy biologiczne mogą być uznawane za przejaw przystosowania się organizmu do rytmiki zdarzeń w środowisku. Pierwszoplanową rolę w tym względzie odgrywa przystosowanie się do cyklu dobowego dnia i nocy oraz do okresowości pór roku. Przyczyną wyżej opisanej rytmiki jest funkcjonowanie Wszechświata, a konkretnie obrót Ziemi wokół własnej osi (ruch wirowy) oraz obieg Ziemi wokół Słońca (ruch obiegowy). To z tych powodów mówi się przede wszystkim o rytmach słonecznych (dzień i noc oraz pory roku), ale także, choć w mniejszym stopniu, o rytmach księżycowych (fazy Księżyca). Do tych pierwszych należą przede wszystkim rytmy dobowe, a do tych drugich - miesięczne ${ }^{58}$. Dzięki tej rytmice wytworzyły się w organizmach żywych odpowiednie mechanizmy przystosowawcze. Jednym z takich mechanizmów jest tzw. zegar biologiczny

Zróżnicowanie dobowe aktywności przejawia się w czuwaniu (aktywności) i śnie (spoczynku). U człowieka z czuwaniem wiąże się świadomość, ze snem zaśczasowe wyłączenie świadomości. Rytmika czuwania i snu odpowiada naturalnej sekwencji dnia i nocy. Czynnikiem synchronizujacym czuwanie i sen jest natomiast Słońce (konkretnie światło słoneczne). U człowieka okresy czuwania i snu sa dodatkowo regulowane wymogami życia społecznego i zawodowego, stylem życia, a także utrwalonymi zwyczajami. Są także regulowane zegarem, ale już nie tyle biologicznym, ile mechanicznym czy elektronicznym, odmierzajaccym czas.

Termin życie w odniesieniu do miasta i jego mieszkańców jest najczęściej stosowany z odpowiednim przymiotnikiem np.: życie codzienne, gospodarcze, rodzinne, towarzyskie, sportowe, kulturalne, osobiste, społeczne, religijne, zawodowe, erotyczne, a ponadto: skomplikowane, ciężkie, pieskie, godziwe, niegodne, na kredyt i wiele innych. Większość z tych wymienionych przymiotników dotyczy przede wszystkim mieszkańców miasta. Stosuje się jednak i takie przymiotniki, które odnieść można do miasta jako jednostki osadniczej i wtedy można mówić o życiu gospodarczym, społecznym, kulturalnym, religijnym, politycznym, sportowym itp. Tak więc na życie miasta składać się także będzie zarówno aktywność mieszkańców, jak i funkcjonowanie szeroko rozumianej infrastruktury miejskiej ${ }^{59}$.

Charakterystyczną cechą miasta jest rytmiczność funkcjonowania tworzących ten system terytorialny elementów, w tym także elementu sprawczego, którym są mieszkańcy. Choć można wyróżniać wiele różnych rytmów obejmujących życie miasta, to jednak wszystkie są, w mniejszym lub większym stopniu, konsekwencją ruchu wirowego Ziemi. Są także efektem właściwości

58 Ibidem; J. Parysek, L. Mierzejewska, Życie miasta. Studium Poznania. Miasto.

59 J. Parysek, L. Mierzejewska, Życie miasta. Studium Poznania. Miasto; iidem, Życie miasta. Studium Poznania. Infrastruktura. 
miasta, traktowanego jako system integrujacy $\mathrm{w}$ granicach miasta podstawowe podsystemy, tj.: przyrodniczy, społeczny i ekonomiczny. Oczywiście innego rodzaju rytmiczność wykazuje przyroda, innego mieszkańcy miasta i struktury społeczne, które tworzą mieszkańcy, a jeszcze inną jest rytmiczność infrastruktury miejskiej, warunkującej życie mieszkańców i funkcjonowanie miasta oraz gospodarki miejskiej. Właśnie te zróżnicowane w czasie przykłady rytmiczności przyrody oraz zachowań ludzkich, działań struktur społecznych, infrastruktury komunalnej i służb miejskich, podmiotów gospodarczych itp. składają się w sumie na ten złożony proces, który nazwać można życiem miasta.

$\mathrm{Na}$ podstawie funkcjonowania w czasie składników systemu miasta można wyróżnić pewne charakterystyczne rytmy funkcjonowania, w tym z cała pewnością rytmy: 1) całodobowe, 2) dzienne, 3) tygodniowe, 4) miesięczne, 5) roczne oraz 6) wieloletnie (tab. 5). Rytmy całodobowe obejmuja te sfery działań ludzkich, które zapewniają nieprzerwane funkcjonowanie miasta i bezpieczeństwo mieszkańców. Rytmy dzienne są konsekwencją dnia i nocy i dotyczą przede wszystkim życia ludzkiego, funkcjonowania gospodarstw domowych oraz życia społecznego i gospodarczego. Rytmy tygodniowe, majace swoje podstawy religijno-kulturowe, także dotyczą funkcjonowania gospodarstw domowych oraz życia społecznego i gospodarczego. Nawiąują przy tym do rachuby czasu i kalendarza. Do kalendarza nawiązują rytmy miesięczne oraz roczne, do czego dostosowana jest organizacja działalności gospodarczej oraz funkcjonowanie instytucji społecznych, przede wszystkim systemu edukacji. Rytmy wieloletnie sa natomiast efektem działania praw przyrody, reguł funkcjonowania społeczeństw i przemian społecznych, zmienności koniunktury gospodarczej itp.

Tabela 5

Rytmy funkcjonowania miasta

\begin{tabular}{|l|l|}
\hline \multicolumn{1}{|c|}{ Rytm } & \multicolumn{1}{c|}{ Podmioty funkcjonujące w danym rytmie } \\
\hline Całodobowy & $\begin{array}{l}\text { podmioty gospodarcze pracujące w ruchu ciagłym, jednostki gospodarki ko- } \\
\text { munalnej (energetyka, gazownictwo, ciepłownictwo, wodociagi, kanaliza- } \\
\text { cja, łączność, komunikacja publiczna itp.), jednostki zabezpieczenia, zdro- } \\
\text { wia, życia i mienia (pogotowie ratunkowe, szpitalne oddziały ratunkowe, } \\
\text { straż pożarna, policja), niektóre placówki handlowe (sklepy całodobowe, } \\
\text { stacje benzynowe) oraz usługowe (pomoc drogowa) }\end{array}$ \\
\hline Codzienny & $\begin{array}{l}\text { osoby, gospodarstwa domowe, podmioty gospodarcze, urzędy, żłobki, przed- } \\
\text { szkola, szkoły różnych typów, placówki ochrony zdrowia, większość placó- } \\
\text { wek handlowych, placówki usługowe, placówki usług komunalnych, pla- } \\
\text { cówki rekreacyjne itp. }\end{array}$ \\
\hline Tygodniowy & $\begin{array}{l}\text { większość zakładów pracy, przedszkola, szkoły, wyższe uczelnie, placówki } \\
\text { kulturalne, zakłady opieki medycznej, placówki sportowe (imprezy), koś- } \\
\text { cioły i inne }\end{array}$ \\
\hline Miesięczny & podmioty gospodarcze, ośrodki wypoczynkowe i rekreacyjne \\
\hline Roczny & $\begin{array}{l}\text { podmioty gospodarcze, jednostki budżetowe w tym szkoły różnych typów, } \\
\text { kościoły, instytucje kulturalne, instytucje sportu i turystyki }\end{array}$ \\
\hline Losowy & imprezy kulturalne i sportowe, zjazdy, konferencje, kongresy itp. \\
\hline
\end{tabular}

Źródło: J. Parysek, L. Mierzejewska, Życie miasta. Studium Poznania. Infrastruktura miejska, Bogucki Wydawnictwo Naukowe, Poznań 2014. 
Wyróżnione rytmy tworzą pewien układ hierarchiczny, determinowany przez kalendarz i czasową organizację prowadzonej działalności. Na szczycie tego układu znajduje się rytm roczny, w który kolejno wpisują się rytmy miesięczne, tygodniowe, całodobowe i dzienne. Rytmy roczne, jak to już napisano, dotyczą przede wszystkim rocznego trybu organizacji i funkcjonowania życia gospodarczego i społecznego, w tym rytmie bowiem funkcjonuja podmioty gospodarcze, które w wymiarze rocznym określają efekty prowadzonej działalności gospodarczej. Planowany na dany rok budżet określa zakres działań wszystkich jednostek gospodarczych i instytucji, zwłaszcza budżetowych. Roczny wymiar mają także awanse zawodowe i finansowe, świadczenia emerytalne i ich weryfikacja, system nagród, premii itp. W wymiarze rocznym prowadzona jest także statystyka dotycząca wielu sfer życia społecznego i gospodarczego ${ }^{60}$.

Edukacja prowadzona jest w wymiarze dość szczególnie określonego roku szkolnego i akademickiego, w ramach których występują okresowe przerwy w nauczaniu, związane $\mathrm{z}$ ruchomymi w czasie feriami zimowymi i świątecznymi - Wielkiejnocy oraz Bożego Narodzenia, a także sesją egzaminacyjna, co dotyczy roku akademickiego. Rozpoczęcie i trwanie roku akademickiego zaznacza się wyraźnie w funkcjonowaniu miasta będącego ośrodkiem akademickim (studenci oraz coraz bardziej powszechne ich samochody). Specyficznie przedstawia się roczny rytm działania placówek kulturalnych określany mianem sezonu artystycznego, który w Polsce trwa w zasadzie od września do czerwca, z wakacyjna przerwą w lecie, trwającą co najmniej 2 miesiące. W podobnym rytmie (sezony) funkcjonują także rozgrywki sportowe, jakkolwiek terminarze rozgrywek są ostatnio rozciagane niemal na cały rok (rozgrywki na otwartych boiskach i rozgrywki halowe). Ściagające większą liczbę osób imprezy sportowe (np. mecze piłki nożnej, zawody żużlowe) są często poważnym zakłóceniem dziennego rytmu życia miasta, zwłaszcza w sferze komunikacji i porządku publicznego. Rytm roczny charakterystyczny jest także dla życia religijnego. W Kościele rzymskokatolickim rok kościelny rozpoczyna się w pierwszą niedzielę adwentu i kończy w sobotę przed kolejną taką niedziela, a kulminacyjnymi punktami tego roku są święta Bożego Narodzenia i Wielkiejnocy oraz inne dni świąteczne. Niektóre uroczystości religijne, zwłaszcza procesje Bożego Ciała, odwiedzanie cmentarzy w dzień Wszystkich Świętych i Dzień Zaduszny, a także dni odpustów w sanktuariach, w zasadniczym stopniu zmieniają dzienne rytmy funkcjonowania poszczególnych miast $^{61}$.

Jakkolwiek rytmy miesięczne składają się właściwie na rytm roczny, to jednak szczególna rola w tym zakresie przypada miesiącom letnim, które sa tradycyjnymi miesiącami wakacyjnymi. To właśnie w miesiącach letnich, inaczej niźli podczas pozostałej części roku, toczy się życie miasta w różnych sferach. Jest to zapewne okres wytchnienia dla mieszkańców tych miast, które nie pełnią funkcji turystyczno-wypoczynkowych. Dla mieszkańców tych ostat-

\footnotetext{
60 J. Parysek, L. Mierzejewska, Życie miasta. Studium Poznania. Miasto.

61 Ibidem.
} 
nich miast nastaja natomiast trudne dni wyraźnego pogorszenia warunków obsługi, jednak dla wielu - polepszenia sytuacji materialnej.

Wprawdzie rytm tygodniowy jest także efektem ram organizacji działania podmiotów życia społecznego i gospodarczego, jednak podstaw tej organizacji należy się doszukiwać w tradycji chrześcijańskiej oraz przyjętych rozwiązaniach socjalnych. W tradycji chrześcijańskiej niedziela była dniem wolnym, dniem świętym, który trzeba było święcić, i tak jest w zasadzie po dziś dzień. W tym dniu należało uczestniczyć w praktykach religijnych, powstrzymywać się od pracy, zwłaszcza zarobkowej, oraz odpoczywać. Postęp naukowo-techniczny oraz cywilizacyjno-kulturowy sprawił, że można było ograniczyć czas pracy do 5 dni w tygodniu. Tego rodzaju rozwiązanie potraktowane zostało także jako zdobycz socjalna osób pracujaccych (tzw. świata pracy). W ten sposób w krajach zachodniego kręgu kulturowego tydzień składa się z 5 dni roboczych oraz 2 dni wolnych od pracy - i to wyznacza tygodniowy rytm funkcjonowania podmiotów życia gospodarczego i społecznego. Z tego rytmu wyłamują się, co jest oczywiste, zakłady produkcyjne i usługowe pracujace w tzw. ruchu ciagłym oraz służby komunalne, służby zabezpieczenia ruchu, komunikacji, ochrony zdrowia, bezpieczeństwa osób i mienia itp. Od pewnego czasu, w 7-dniowym, tygodniowym rytmie funkcjonują jednak niektóre placówki handlowe, zwłaszcza wielkopowierzchniowe centra handlowe. Pięciodniowy tydzień pracy zatrudnionych w tych placówkach jest teoretycznie zabezpieczony w ramach odpowiednich rozwiazań organizacyjnych. Należy jednak w tym miejscu podkreślić, że w wielu państwach Europy Zachodniej praca w soboty i niedziele jest poważnie ograniczona odpowiednimi regulacjami prawnymi. Niestety, w Polsce coraz więcej osób zmuszanych jest do pracy w dni ustawowo wolne od pracy, głównie w tzw. wielkomiejskich „świątyniach konsumpcji”62. Podobnie ma się sprawa z funkcjonowaniem tzw. sklepów nocnych (czynnych 24 godziny), co nie znajduje żadnego logicznego uzasadnienia, zwłaszcza że podstawowym artykułem sprzedaży nocnej jest alkohol.

Specyficzny tygodniowy rytm pracy dotyczy placówek kulturalnych. Kina prowadzą swoją działalność właściwie każdego dnia, przede wszystkim jednak w godzinach popołudniowych i wieczornych oraz w dni wolne od pracy. Muzea i galerie wystawowe sa zazwyczaj czynne każdego dnia. Dla teatrów dramatycznych, teatrów operowych, innych muzycznych, lalkowych itp. dniem wolnym od prowadzonej działalności jest najczęściej poniedziałek. Koncerty symfoniczne odbywają się natomiast generalnie w piątki, a czasami także w soboty lub niedziele. Dniem koncentracji nabożeństw religijnych jest natomiast niedziela, a także dni świąt kościelnych.

Generalnie 5-dniowy dzień nauki obowiąuje także w przedszkolach oraz szkołach różnych szczebli. Placówki prowadzące działalność dydaktyczna $\mathrm{w}$ trybie niestacjonarnym kształcenie prowadzą również w soboty i niedziele. Pięciodniowy tydzień pracy jest także charakterystyczny dla placówek ochro-

${ }^{62}$ W. Maik, op. cit. 
ny zdrowia, jakkolwiek pewne z tych placówek świadczą tzw. pomoc doraźna w dni wolne od pracy. Siedmiodniowa i całodobowa jest natomiast praca pogotowia ratunkowego i szpitalnych oddziałów ratunkowych.

W rytmie dziennym, wyznaczonym przez dzień i noc oraz fizjologię organizmu ludzkiego, funkcjonuje człowiek i jego gospodarstwo domowe. Do tego rytmu dostosowuje się funkcjonowanie zdecydowanej większości placówek pokrywających różnorakie potrzeby społeczne, w tym także niektórych służb komunalnych.

Dzień i noc wyznaczają podstawowy rytm funkcjonowania człowieka. Doba dzielona jest na czas pracy, względnie nauki, czas załatwiania spraw związanych z funkcjonowaniem gospodarstwa domowego, czas wypoczynku i rozrywki itp. (czas aktywności) oraz czas snu.

Rytm dzienny jest jednak tym, który w zasadniczym stopniu kształtuje życie miasta, tj. jego funkcjonowanie w czasie. W rytmie całodobowym, tj. 24-godzinnym, funkcjonuja, jak to już powiedziano, zakłady pracujące w ruchu ciagłym, komunikacja pasażerska, zwłaszcza dalekobieżna, hotele, służby komunalne, służby zabezpieczenia zdrowia, życia oraz mienia, a także niektóre placówki handlowe i usługowe.

Można także wyróżnić rytm losowy, który dotyczy przede wszystkim różnego rodzaju zjazdów, konferencji i kongresów oraz imprez sportowych, kulturalnych i rozrywkowych, które organizowane sa w konkretnym mieście przez zewnętrzne lub wewnętrzne agencje imprezowe lub przez władze miejskie. Także i tego rodzaju wydarzenia w określonym stopniu zmieniaja „normalny” rytm życia miasta ${ }^{63}$.

Choć w niniejszej pracy przytoczono kilka różnych kategorii rytmów życia miasta, to jednak należy mieć świadomość tego, że generatorem wszystkich tych rytmów jest człowiek oraz jego szeroko rozumiane funkcjonowanie, związane przede wszystkim z działaniami na rzecz zaspokojenia podstawowych potrzeb. Temu też celowi służą właściwie cała infrastruktura i suprastruktura miejska i ich funkcjonowanie. Należy więc przyjąć, że pierwszoplanową rolę w kształtowaniu życia miasta odgrywają jego mieszkańcy. Jednakże w latach dużej dynamiki procesów suburbanizacji oraz wzrostu stopnia centralności niektórych miast na życie miasta znaczący wpływ mają także mieszkańcy strefy podmiejskiej oraz osoby przyjezdne ${ }^{64}$.

\footnotetext{
63 J. Parysek, L. Mierzejewska, Życie miasta. Studium Poznania. Miasto.

${ }^{64}$ J. Parysek, Suburbanizacja $i$ dezurbanizacja: dwa bieguny polskiej urbanizacji, w: J. Parysek, T. Stryjakiewicz (red.), op. cit., s. 261-286; J. Parysek, Procesy suburbanizacji w aglomeracji poznańskiej, w: T. Kaczmarek, A. Mazgajski (red.), Powiat poznański. Jakość przestrzeni i jakość życia, Bogucki Wydawnictwo Naukowe, Poznań 2008, s. 71-90; J. Parysek, Aglomeracje miejskie, s. 31-54; J. Parysek, L. Mierzejewska, Między dezurbanizacja a reurbanizacja, w: I. Jażdżewska (red.), Współczesne procesy urbanizacji i ich skutki, Wyd. UŁ, Łódź 2005, s. 47-56; J. Parysek, L. Mierzejewska, Two Stages in Postwar Urbanisation in Poland: From Socialist to Postmodern Urbanisation, w: Y. Murayama, G. Du (red.), Cities in Global Perspective: Diversity and Transition, Rikkyo University with IGU Urban Commission, Tokyo 2005, s. 72-82; T. Czyż, Koncepcja aglomeracji miejskiej i obszaru metropolitalnego $w$ polskiej geografii miast, w: W. Maik (red.), op. cit., s. 15-30.
} 


\section{ZAKOŃCZENIE}

W niniejszym artykule przedstawiono trzy modele systemowego ujęcia miasta. W pierwszym miasto traktuje się jak terytorialny system społeczny, $\mathrm{w}$ drugim - tak jak ekosystem, a w trzecim - jak organizm żywy. W każdym $\mathrm{z}$ tych ujęć ma miejsce odwzorowanie miasta jako funkcjonalnej całości, przy uwzględnieniu jego organizacji, struktury, a po części także funkcjonowania. Tak interpretowane miasto może być nie tylko przedmiotem badań naukowych pozwalających w niekonwencjonalny sposób uchwycić jego naturę i funkcjonowanie, ale także przedmiotem działań praktycznych. Podczas gdy w pierwszym przypadku systemowe ujęcie miasta (miasto jako terytorialny system społeczny), oznacza odwzorowanie jego organizacji, struktury i funkcjonowania, prowadzace do bardziej pełnego opisu i diagnozy stanu istniejącego, to w drugim przypadku ujęcie systemowe może być wysoce użytecznym narzędziem planowania oraz koordynacji rozwoju. W tym drugim przypadku w grę wchodzić może zarówno rozwój społeczno-gospodarczy, jak i przestrzenny, w szerokim tych działań rozumieniu. I choć każdy z przedstawionych modeli może mieć efektywne zastosowanie na wielu etapach różnych działań planistycznych i koordynacyjnych, to jednak miasto traktowane jako terytorialny system społeczny wykazuje szczególną użyteczność przy określaniu przedmiotu działań planistycznych, zarówno w planowaniu społeczno-gospodarczym, jak i przestrzennym, model miasta-ekosystemu, przy planowaniu zagospodarowania przestrzennego, formułowaniu kierunków polityki urbanistycznej i ekologicznej oraz kształtowaniu środowiska życia, natomiast model miasta-organizmu - w planowaniu oraz koordynacji rozwoju społeczno-gospodarczego i przestrzennego i wyznaczaniu kierunków polityki miejskiej. To ostatnie ujęcie może ponadto odegrać szczególną rolę w dostosowaniu poziomu rozwoju infrastruktury miejskiej oraz struktury przestrzenno-funkcjonalnej miasta do potrzeb mieszkańców oraz ich aktywności czasowej ${ }^{65}$.

Współczesne miasto jest niezwykle złożonym systemem przestrzennym, którego rozwoju nie da się efektywnie koordynować i planować bez świadomości holistycznej i funkcjonalnej, a zatem i systemowej natury. Świadomość takiego stanu rzeczy powinna towarzyszyć, z jednej strony, władzom samorządowym miasta i politykom aspirującym do sprawowania władzy w mieście, a z drugiej - planistom nakreślającym kierunki rozwoju społeczno-gospodarczego i przestrzennego miasta. O takiej całościowej i funkcjonalnej naturze miast powinni także wiedzieć ich mieszkańcy, tylko bowiem wtedy mogą się świadomie i konstruktywnie włączyć w proces uspołecznienia planowania rozwoju miasta, co w sposób bezpośredni prowadzi do zmiany modelu sprawowania władzy, czyli odejścia od rządzenia i zarządzania i przyjęcia modelu

${ }^{65}$ J. Parysek, L. Mierzejewska, Życie miasta. Studium Poznania. Miasto; iidem, Życie miasta. Studium Poznania. Infrastruktura. 
współrządzenia czy współzarządzania ${ }^{66}$. Jeśli miasto ma być funkcjonalnym i przyjaznym środowiskiem życia mieszkańców, to nie ma innego sposobu na osiagnięcie tego celu, jak poprzez systemowe spojrzenie na jego organizację, strukturę i funkcjonowanie.

prof. dr hab. Jerzy J. Parysek

Uniwersytet im. Adama Mickiewicza w Poznaniu

parys@amu.edu.pl

\section{A SYSTEMIC APPROACH TO THE CITY}

Sum mary

Since L. von Bertalanffy's formulation of his general systems theory examined and moulded by the reality, as long as it is a functioning whole system, that theory has been treated as a system. This systemic concept appears particularly useful when researching and planning the development and operation of units of territorial administrative division, including cities. In recognition of the role of the systemic approach in cognitive research and the planning of socio-economic and spatial development, three systemic models are presented in which the city is treated as: (i) a territorial social system, (ii) an ecosystem, and (iii) an organism. Although each of these models can be employed effectively at various stages of the planning and coordination process, the one of the city as a territorial social system is especially useful when defining the object of planning activities, both in socio-economic and spatial planning; the city-as-ecosystem model when planning spatial development, formulating the direction of town-planning and ecological policies and the shaping of the living environment; whilst the city-as-organism model, in the planning and coordination of socio-economic and spatial development as well as setting the directions of urban policy. The latter approach can also play a special role in adjusting the level of development of a city's infrastructure and its spatial-functional structure to the needs of its inhabitants in their everyday lives.

${ }^{66}$ J. Parysek, A. Toelle (red.), Urban Development and Urban Governance, Quaestiones Geographicae 26 B, WN UAM, Poznań 2007; J. Parysek, Rozwój miast a polityka miejska; idem, Urban Development Policy. 
